\title{
The Debate about the definition of the Mexican Violent Conflict: towards a useful concept
}

\author{
Presented in the $26^{\text {th }}$ World Congress of Political Science \\ International Political Science Association \\ $11^{\text {th }}$ July 2021
}

Raúl Zepeda Gil ${ }^{1}$

\begin{abstract}
Since 2007, scholars and the general public have tried to understand the nature of the increasingly violent conflict in Mexico. As a result, many different concepts, and characterisations about the violence in Mexico have arisen, but many of these, either borrowed from many fields of literature terms or new concepts, fall short to classify or explain the key differences from high scale violence involving organised crime and other types of violent conflicts such as civil wars. Also, considering the regional trend of high homicide rates in Latin America, especially in Central America and Brazil, it is relevant to build a new concept that can be useful, theoretically, and empirically, for the study of violence and conflict derived from involvement of organised crime, gangs, and other nonstate actors. In this article I review most of the academic and political commentary of the nature of the Mexican case and, from there, I analyse the different concepts proposed from two angles: first, a comparison with the characteristics of other high scale violent conflict concepts, and second, an examination of their utility in terms of theory, field studies, internal coherence, parsimony, familiarity, depth, differentiation, and familiarity. The aim of the comparison of different types of conflict is to assess how scholars use the literature from diverse fields to influence categorisation of new violent phenomenon. The examination of utility aims is to establish how these comparisons help or not to study of violence in Mexico and other Latin America cases of high scale violence of non-political conflicts, and how characterisations and evidence collected can enhance the understanding of violence with the building of a useful concept of this phenomenon.
\end{abstract}

\footnotetext{
${ }^{1}$ PhD Candidate, Defence Studies Department, King’s College London. Email: zepeda.raul@kcl.ac.uk.
} 


\section{Introduction}

Contemporary violence in the scale witnessed in Latin America since the early 1990s are a new subject of study that has been grappled partially by scholars in several fields: economics, political science, anthropology, sociology, and history. Naturally, violence in high levels of occurrence committed by criminal organisations is a challenging phenomenon to explain. Moreover, when all these fields of study have different interpretations of how violence or criminal organisations behave.

My main argument is that many of the trends of what is happening in Mexico can be confused into the boundaries of a wide range of concepts that are discussed in many fields of social sciences, because Mexico, as other countries in Latin America, are part of a new trend of violence that is not political but not entirely interpersonal or 'private'. By using these concepts, many of the scholars haven't noticed that they are not only bypassing the importance of the boundaries in their fields, also are drawing concepts that are essentially contested.

The example of the use of civil war to describe what happens in organised crime is the perfect example of this tendency. As Kalyvas argues, the literature in civil wars relay on the political content of civil wars, different as in organised crime that is driven by profit and protection rackets. ${ }^{2}$ Even if some trends of organised crime present themselves in civil wars like profiteering ${ }^{3}$ and rebel governance as racket protection ${ }^{4}$, Kalyvas argues that the main drivers of civil war still are political motivations. ${ }^{5}$

Certainly, concepts like civil wars are ideal types ${ }^{6}$ and simultaneously essentially contested concepts ${ }^{7}$ because of the changing historic trends of violence and conflict. The history of concept formation is directly linked to the history of ideas and how those are formed in their contexts and responding to trends of their times. ${ }^{8}$ In this case, war and violence are intrinsically connected by state making and state formation, ${ }^{9}$ so it is natural that researchers find from the seminal work of Tilly answers of how to understand high scale violence.

In this paper I will address and support the concept of criminal war. Lessing formally coined the concept of criminal wars. It is grounded in the historical examples of battles between criminal organisations - either called turf, gang, or bandit wars-, criminal wars

2 Kalyvas, Stathis N. "How civil wars help explain organized crime—and how they do not." Journal of Conflict Resolution 59.8 (2015): 1517-1540.

3 Kaldor, Mary. New \& Old Wars. Polity, 2006.

4 Arjona, Ana, Nelson Kasfir, and Zachariah Mampilly, eds. Rebel governance in civil war. Cambridge University Press, 2015.

5 Kalyvas, Stathis N. "" New" and" Old" Civil Wars: A Valid Distinction?." World Politics (2001): 99-118.

6 Weber, Max. Economy and society: An outline of interpretive sociology. Vol. 1. Univ of California Press, 1978.

7 Gallie, W. B. "IX.-Essentially Contested Concepts." Proceedings of the Aristotelian Society. Vol. 56. No. 1. Oxford, UK: Oxford University Press, 1956.

8 Skinner, Quentin. "Meaning and Understanding in the History of Ideas." History and Theory 8.1 (1969): 353.

9 Tilly, Charles. "War Making and State Making as Organized Crime." Chapter. In Bringing the State Back In, edited by Peter B. Evans, Dietrich Rueschemeyer, and Theda Skocpol, 169-91. Cambridge: Cambridge University Press, 1985. 
have developed in Latin America since the late 1990. After the so-called "lost decade" of growth, the region experienced a sustained economic development trend. ${ }^{10}$ Nonetheless, growth in this period unequal. Also, this decade showed a vital process of democratisation, pacification after civil wars, and widespread state repression. Simultaneously, a new wave of militarised responses due to the United States Government's pressure on regional drug trafficking. Mexico was therefore suffering a perfect storm: growing illicit drug trafficking in booming, deregulated, and open economies, tackled by the armed forces primarily using kinetic force. The result was that Latin America had become a region as deadly as countries experiencing civil wars. Since then, criminal organisations have resisted military crackdowns while simultaneously advancing their market capture of various illicit goods, especially marihuana, and poppy to create heroin and synthetic drugs such as ecstasy and methamphetamines. ${ }^{11}$

Although the studies of conflict, war, violent crime, and terrorism share common topics, this literature review of the conduction of criminal wars in Latin America deals with the novelty of this kind of conflicts before revising and appropriately adapting or discarding elements from these areas. This review aims to illustrate the general findings and dynamics of violence in the current criminal wars towards a better understanding of this concept's usage and question the vast concept stretching used for these cases. The novelty of the phenomena led researchers, scholars, journalists, and policymakers to borrow concepts from other literature fields. However, it is necessary to clarify and distinguish a criminal war to separate them from other phenomena related to civil wars, but not the same because of different ontological, epistemological, and practical reasons.

\section{The conceptual struggle for criminal wars}

Besides the obvious comparisons between civil wars and criminal wars, these research subjects have been used to compare the current trend of homicide in Latin America. Researchers, journalists, and government have used a wide range of concepts to describe the dynamics of violence or the participants in it. Understandably, some of them are essential intellectual efforts to comprehend such a novel and complex issue. Nonetheless, some comparisons reach exaggerations or understandable misconceptions.

There are two examples of this discussion: state failure and criminal insurgencies. In the first case, Kenny and Serrano criticised the use of this essentially contested concept to qualify a situation that could represent more of a collapse of part of the state apparatus. This collapse happened after the State confronted an unexpected retaliation of criminal organisations after

10 The 'lost decade' is the period known from the late 1970s to the early 1980s in which most of Latin America experienced an overall debt crisis that led to the collapse of the banking system in the region. The International Monetary Fund and the U.S. Government implemented a series of fiscal restraint reforms to control the rising debt, stabilise financial markets, and implement liberalisation policies oriented to dismantle the model of import substitution industrialisation. This can be reviewed in detail in chapter 5 of Bértola, Luis, and José Antonio Ocampo. The economic development of Latin America since independence. OUP Oxford, 2012.

${ }^{11}$ On this, revise chapter 4 of Bergman, Marcelo. More money, more crime: Prosperity and rising crime in Latin America. Oxford University Press, 2018. 
the Army's deployment in 2006 than a whole collapse of the Mexican State. ${ }^{12}$ Indeed, violence and criminal governance in regions of Mexico are indicative of state weakness. However, the heavy burden of the ideological implications of failed state paraphernalia in the U.S. foreign policy frame leads to discussions closer to Western ideals of the State than its actual development in Latin America. ${ }^{13}$

In the second case, the civil war terms filtrated easily into the Mexican discussion, especially by two authors: Ioan Grillo's El Narco: inside Mexico's criminal insurgency ${ }^{14}$ and Andreas Schedler's En la niebla de la Guerra ("In the fog of war"). ${ }^{15}$ As argued by Kalyvas, ${ }^{16}$ using terms based on the research program of civil war can head to misleading interpretations. Grillo mischaracterises the ontological origin of criminal organisations by using the term criminal insurgency. Also, he gives the false impression that these organisations use the same mechanisms, techniques, ideas, and mobilisation repertoire used by guerrillas. Schedler situates Mexico's political regime as the central part of the conflict by using the concept of civil war.

On the contrary, as Varese explains for the cases of mafias and democratic tensions in Hong Kong and Russia, democracy is a space of opportunity for offering racketeering services to politicians or pressure groups. ${ }^{17}$ In this case, democracy is the scenario, but not the main explanatory structure of violence and crime, that also existed in socialists economies, such as the Soviet Union or several parts of Africa. ${ }^{18}$ Of course, Varese cases do not explain how mafias create high scale violence in Latin America. However, his insights in organised crime literature are closer to criminal organisations in Mexico than guerrillas.

The concept stretching ${ }^{19}$ of scholars and journalists exemplified here is part of a broader historical process of building a research program around the criminal war question. In terms of Lakatos, all theories have fundamental presumptions that distinguish them from other theories. That is called hardcore. Subsequently, there is evidence on the hardcore and

12 Kenny, Paul and Mónica Serrano. "Introduction: Security failure versus state failure." In Mexico's Security Failure, pp. 13-38. Routledge, 2013, pp. 13-38. Kenny and Serrano summarise the various articles, either academic or opinion pieces, that portrayed Mexico as a failed state.

13 A fine criticism of the failed state agenda can be found in Call, Charles T. "The fallacy of the 'Failed State'." Third World Quarterly 29, no. 8 (2008): 1491-1507.

14 Grillo, Ioan. El Narco: inside Mexico's criminal insurgency. Bloomsbury Publishing USA, 2012.

15 Schedler, Andreas. En la niebla de la guerra (2da. Edición): Los ciudadanos ante la violencia criminal organizada. CIDE, 2018. De la Calle, Luis, and Andreas Schedler. "¿Borrón sin cuenta nueva? La injusticia transicional en guerras civiles económicas." Revista Perfiles Latinoamericanos 29, no. 57 (2020).

16 Kalyvas, Stathis N. "How civil wars help explain organized crime-and how they do not." Journal of Conflict Resolution 59, no. 8 (2015): 1517-1540.

17 Revise Varese, Federico. Mafia Life: Love, Death, and Money at the Heart of Organized Crime. Oxford University Press, 2018, chapter 7, and Varese, Federico. The Russian Mafia: private protection in a new market economy. Oxford University Press, 2001. Varese, Federico. "The transition to the market and corruption in post-socialist Russia." Political studies 45, no. 3 (1997): 579-596.

18 Revise Bayart, Jean François, Stephen Ellis, and Beatrice Hibou, The Criminalization of the State in Africa, James Currey, London, 1999.

19 Sartori, Concept misformation in comparative politics, p. 1051: "At this stage of the argument I need not labor at explaining why and how we obtain these drastic losses of specifity. They result, as we know, from conceptual stretching, which results, in turn, from incorrect ladder climbing: the clumsy attempt to arrive at "travelling universals" at the expense of precision, instead of at the expense of connotation (i.e., by reducing the number of qualifying attributes). What remains to be highlighted are the consequences of this state of affairs." 
peripheral research that supports it. On the research process, even when further research discards peripheral findings, a theory does not become obsolete. If the hardcore remains falsifiable and resistant to tests, the theory remains. ${ }^{20}$ In criminal wars, basic assumptions are currently in development. More sophisticated scholarship on Latin America has appeared, which will be reviewed below. This research is part of the primary endeavours of the building of the hardcore of criminal wars theory. However, this research will face the constant muddle of fitting convergences and divergences surrounding a novel phenomenon in this process. Other theories seem fit to explain some events, characteristics, and features, but not always.

In particular, researchers have found convergences of criminal wars on several angles, such as violence logics and techniques, conformation and motivations of non-state violent organisations, protection racketeering and illicit traffic activities, patterns of diffusion of homicide, onset, duration and termination of conflicts, and this primary research interest: mobilisation mechanisms, structures, and individual profiles of violence experts. As said before, it can be understood on macrostructural theories, meso-organisational studies of violent non-state actors, and micro behavioural profiles. This research will summarise them to find the convergences useful for the research. Nevertheless, for clarity: each of these concepts must be tested and built congruently with criminal wars' nature. Moreover, some of them probably are contested ${ }^{21}$ within their fields. Therefore, empirical results must lead to adaptations or reinterpretations.

The literature on organised crime did not conceive the massive use of violence as part of the standard repertoire of actions that these organisations could engage. Also, the studies of war and conflict have struggled with the possibility of non-state actors that do not have profound and inheritable ideological motivations. In the case of organised crime literature, Gambetta in The Sicilian Mafia portrays the political economy of organised crime sharply. However, he argues that violence is inherently costly and usually avoided but can happen under certain circumstances. ${ }^{22}$ In civil war literature, scholars use Kalyvas' The Logic of Violence in Civil War for explaining organised crime violence because he describes how violence is used strategically in conflict. ${ }^{23}$ However, it is essential to remind that his focus is on political violence, not criminal.

Nonetheless, both Gambetta and Kalyvas books' seminal clarity understand the perfectly ontological source of their subjects' motivations and engage frame their research on the landscape of strategic decisions. Unsurprisingly, scholars have employed both books complementarily to explain criminal wars in Latin America. One of them is useful for the inherent motivations and structures of organised crime, and the other on the uses of violence

20 On the logic of research programs revise Lakatos, Imre. "Falsification and the methodology of scientific research programmes." In Can theories be refuted?, Springer, Dordrecht, pp. 205-259, and chapter 9 of Chalmers, Alan F. What is this thing called science?. Hackett Publishing, 2013, pp. 121-137.

21 On essentially contested concepts revise Gallie, Walter Bryce. "Essentially contested concepts." In Proceedings of the Aristotelian society, vol. 56, pp. 167-198. Aristotelian Society, Wiley, 1955, and Collier, David, Fernando Daniel Hidalgo, and Andra Olivia Maciuceanu. "Essentially contested concepts: Debates and applications." Journal of Political Ideologies 11, no. 3 (2006): 211-246. For us, the use of any concept depends more in how those concepts are historically replied and solidly tested rather than logically formulated.

22 Gambetta, Diego. The Sicilian Mafia: the business of private protection. Harvard University Press, 1996.

23 Kalyvas, Stathis N. The logic of violence in civil war. Cambridge University Press, 2006. 
against the State. This research proposes that criminal wars in Latin America are the reflection of these two phenomena.

Lessing coined the term criminal war because these two words together can be a good concept, as defined by Gerring. ${ }^{24}$ Paradoxically, Lessing, either in his book or his seminal article, ${ }^{25}$ does not define criminal wars. Instead, he underlines his theory of their logic and proposes a typology of criminal wars. The logic of his violent lobbying theory is the component of his concept. This decision is understandable because Lessing wants to differentiate disputes between criminal organisations (turf wars) and the State (cartel-State). However, he and other scholars recognise a grey zone between cartel and turf wars. Even as he recognises that the international drug prohibition regime is the source of these conflicts, he does not incorporate that historical grounding in his conceptual definition. His classification might be more inclusive and comparable for more cases, but there is an essential digression in terms of Sartori: ${ }^{26}$

All in all, then, it can hardly be held that our "losses of specificity" are compensated by gains in inclusiveness. I would rather say that our gains in travelling capacity, or universal inclusiveness, are verbal (and deceptive) while our "gains in obfuscation" are very substantial.

Only directionality or logics of violence are not enough to give the concept of criminal wars the strength to understand what happens in Mexico. Moreover, profit cannot be enough as the distinction. The massive use of violence or change of policy via violent lobbying either. The source of the use of violence for profit and the need for changing the enforcement policies and capacities of government comes from the simple fact that criminal organisations are illegal. The illegality of their profitable activities is central to criminal wars.

Indeed, there is a strictly legal argument against this research: insurrection, guerrilla warfare, or terrorism are illegal. Nonetheless, those are illegal activities because they have in their central core the overthrow of the government. These crimes are in the realm of national security law, international law of conflict and war, and international criminal law. In the case of illicit goods, this is in internal criminal law codes. Securitisation by militarisation in the drug realm is real, and some interlopers of those fields have arisen. However, the subject still is the regulation of a private market. Even other illicit profitable activities deserve so much militarised attention as drugs because of the international drug prohibition regime's national enforcement. $^{27}$

24 Gerring, John. "What makes a concept good? A criterial framework for understanding concept formation in the social sciences." Polity 31, no. 3 (1999): 357-393.

25 Lessing, Making Peace in Drug Wars, chapters 2, 3 and 4, and Lessing, Benjamin. "Logics of violence in criminal war." Journal of Conflict Resolution 59, no. 8 (2015): 1486-1516.

26 Sartori, Giovanni. "Concept misformation in comparative politics." American Political Science Review 64, no. 4 (1970), p. 1052.

27 This falls into the wide discussion on securitisation, legal reforms, and national security agendas. Indeed, the issue of drug consumption, trafficking and production has been transformed from the criminal law to the national security frameworks in several countries, falling into the process that Buzan, Weaver and De Wilde proposed. Andreas and Nadelmann argue that the international prohibition regime overlaps between the treaties, the national security agendas, but relay mainly in the implementation of criminal law. Revise: Andreas, Peter, and Ethan Nadelmann. Policing the globe: Criminalization and crime control in 
Scholars on Latin American Criminal Wars emphasise that militarised interventions are the source of violent retaliation by criminal organisations. Some argue that those wars come from conflicts between criminal organisations, independent from governments policies: turf wars. Nonetheless, evidence points out that the onset of these wars' most violent phases came from the United States Government's pressure. This pressure led to the escalation of their enforcement operations in the region via military forces. ${ }^{28}$ That is why there are high homicide rates in the region before the 1990s.

Beyond the onset, the U.S. government has regularly pressured Latin American governments for military operations against drug trafficking. Therefore, there are not two types of criminal war. There are no turf wars and criminal wars. Both are the same type of war in phases: first prohibition and low prosecution, even protection, then crackdowns to enforce prohibition by military means, and then an inter-cartel conflict for territorial gains after drug market disruptions.

All the region cases show that the military has intervened with their tactics, such as dismantling organisations with violence rather than detentions, substituting policing techniques. ${ }^{29}$ That is the reason behind the high homicide rates in cities of the United States or Europe produced by gangs, ${ }^{30}$ more disorganised, as Reuter says, ${ }^{31}$ but not militarised interventions because the United States and European governments do not implement the prohibition regime in their territories in the same ways as Latin America. They do it by policing brutality and race labelling. ${ }^{32}$ In Latin America, a full-scale military challenge can only have two consequences for criminal organisations. These entrepreneurial organisations

international relations. Oxford University Press, 2008. Buzan, Barry, Ole Wæver, and Jaap De Wilde. Security: A new framework for analysis. Lynne Rienner Publishers, 1998.

28 For this revise: Andreas, Peter. "Free market reform and drug market prohibition: US policies at crosspurposes in Latin America." Third World Quarterly 16, no. 1 (1995): 75-88. Nadelmann, Ethan A. "Drug prohibition in the United States: Costs, consequences, and alternatives." Science 245, no. 4921 (1989): 939947. Levine, Harry G. "Global drug prohibition: its uses and crises." International Journal of Drug Policy 14, no. 2 (2003): 145-153. Serrano, Mónica, "Unilateralism, Multilateralism, and U.S. Drug Diplomacy in Latin America", in Malone, David M. y Foong Khong, Yuen, Unilateralism and U.S. Foreign Policy: International Perspectives, London, Lynne Reinner Publishers, 2003, pp. 117-138. Andreas, Peter, and Ethan Nadelmann. Policing the globe: Criminalization and crime control in international relations. Oxford University Press, 2008.

29 Garzón, Juan Carlos y Bailey, John, "Displacement Effects of Supply-Reduction Policies in Latin America. A Tipping Point in Cocaine Trafficking, 2006-2008”, in Brownstein, Henry H. (ed.), The Handboook of Drugs and Society, New York, 2016, pp. 482-523. Flores-Macías, Gustavo A., and Jessica Zarkin. "The militarization of law enforcement: Evidence from Latin America." Perspectives on Politics (2019): 1-20. Flores-Macías, Gustavo. "The Consequences of Militarizing Anti-Drug Efforts for State Capacity in Latin America: Evidence from Mexico." Comparative Politics 51, no. 1 (2018): 1-20. Pion-Berlin, David, and Harold Trinkunas. "Latin America's growing security gap." Journal of Democracy 22, no. 1 (2011): 39-53.

30 This can be reviewed in Hagedorn, John. A world of gangs: Armed young men and gangsta culture. Vol. 14. U of Minnesota Press, 2008. Hagedorn, John M. "The global impact of gangs." Journal of Contemporary Criminal Justice 21, no. 2 (2005): 153-169.

31 Reuter, Peter. Disorganized crime: The economics of the visible hand. Cambridge, MA: MIT press, 1983. 32 A review on the process of massive criminalisation of the black population in the US can be seen in Hinton, Elizabeth, and DeAnza Cook. "The Mass Criminalization of Black Americans: A Historical Overview." Annual Review of Criminology 4 (2020). A review focused in the United Kingdom can be found in Williams, Patrick. "Criminalising the other: Challenging the race-gang nexus." Race \& Class 56, no. 3 (2015): 18-35. 
will either perish or transform themselves, mafias (or protection rackets), ${ }^{33}$ into fully operational armies.

The fundamental mistake of all the literature that has struggled with violence in Latin America is that they overstate the criminal organisations' members motivations. However, they underscore the State's actual motivations and actions. In this case study, we discuss how the State deploys its military capacity against criminal organisations, leading to increased violence in the region. Duran Martínez, Lessing, Trejo and Ley, Wolf, Yashar, Pion-Berlin and Trinkunas, Castillo and Kronick, Moncada, and Koonings, ${ }^{34}$ have carried through the analysis of the increase of violence in Latin America. However, they all have a remarkable coincidence: military or military warfare usage has led to increased violence. Alternatively, in Central America, the massive deportation of gang members from the United States to El Salvador and Guatemala created almost instantly brand-new criminal armed organisations. ${ }^{35}$ None of the cases they have studied escapes from the influence of the United States Government or the prohibition regime in the use of militarised violence. ${ }^{36}$

33 Gambetta, The Sicilian Mafia, p. 20. As conceptualised by Gambetta, Mafias are foremost protection rackets that provide security services for another criminal activities. It is not necessary that these also have the entrepreneurial activities such as drug trafficking. Their business is protection. Nonetheless, mafia literature recognised hybrids of mafias, gangs, and transnational drug trafficking organisations.

34 Durán-Martínez, Angélica. The politics of drug violence: Criminals, cops and politicians in Colombia and Mexico. Oxford University Press, 2017. Lessing, Making Peace in Drug Wars. Trejo, Guillermo, and Sandra Ley. Votes, Drugs, and Violence: The Political Logic of Criminal Wars in Mexico. Cambridge University Press, 2020. Wolf, Sonja. "El control de pandillas en la relación El Salvador-Estados Unidos." Foreign Affairs Latinoamérica 9, no. 4 (2009): 85-96. Yashar, Deborah J. Homicidal ecologies: illicit economies and complicit states in Latin America. Cambridge University Press, 2018. Pion-Berlin, David, and Harold Trinkunas. "Latin America's growing security gap." Journal of Democracy 22, no. 1 (2011): 39-53. Castillo, Juan Camilo, and Dorothy Kronick. "The Logic of Violence in Drug War." American Political Science Review 114, no. 3 (2020): 874-887. Moncada, E. The Politics of Urban Violence: Challenges for Development in the Global South. St Comp Int Dev 48, 217-239 (2013). Koonings, Kees. "New Violence, Insecurity, and the State: Comparative Reflections on Latin America and Mexico." In Violence, Coercion, and State-Making in Twentieth-Century Mexico (2012): 255-278. Cruz, José Miguel. "State and criminal violence in Latin America." Crime, Law and Social Change 66, no. 4 (2016): 375-396.

35 Miguel Cruz, José. "Central American maras: from youth street gangs to transnational protection rackets." Global Crime 11, no. 4 (2010): 379-398. Ambrosius, Christian. "Deportations and the roots of gang violence in Central America." Criminal Justice, Borders and Citizenship Research Paper 3225314 (2018). Wolf, Sonja. "Maras transnacionales: Origins and transformations of Central American street gangs." Latin American Research Review 45, no. 1 (2010): 256-265.

36 An important caveat is necessary for the case of Brazil. Indeed, apparently, as Lessing argues (chapter 6, Making Peace in Drug Wars), the scenario of criminal wars in that country has been mostly Rio de Janeiro. And of course, military, and local police forces seem to copy military techniques from other countries to confront gangs in the favelas. There are indeed a national roots of prohibition regimes as Gootenberg and Campos in all Latin America. Yet, as Nadelmann argues that drug policy is an export not only acquired by pressure, also by imitation. And, as Mora defends, the effect of militarised efforts of Andean governments in South America spilled over Brazil and eventually created a vacuum that the military in Brazil took advantage for internal political purposes. On this, revise: Mora, Frank O. 1996. "Victims of the Balloon Effect: Drug Trafficking and U.S. Policy in Brazil and the Southern Cone of Latin America." The Journal of Social, Political, and Economic Studies 21 (2) (Summer): 115. Nadelmann, Ethan A. "US drug policy: A bad export." Foreign Policy 70 (1988): 83-108. Gootenberg, Paul, and Isaac Campos. "Toward a new drug history of Latin America: A research frontier at the center of debates." Hispanic American Historical Review 95, no. 1 (2015): 1-35. Lima, Raphael C., Peterson F. Silva, and Gunther Rudzit. "No power vacuum: national security neglect and the defence sector in Brazil." Defence Studies (2020): 1-23. 


\section{A criminal war concept}

Following this argument, I propose the concept of criminal war: a violent conflict between the State and criminal organisations, produced by the militarised use of the State to implement a prohibition regime of any illicit goods, and the sustained violent resistance and lobbying by mafias dedicated to profitable illicit traffic, transformed into non-state violent armies.

In the next paragraphs, I will defend this concept. Moreover, I will show the fundamental political economy traits of the concept. The aim is to build the socioeconomic mobilisation process that criminal organisations need to confront a military intervention by the State successfully. In line with Sartori's view, this concept can travel because it does not explicitly mention the drug prohibition regime, which is historically grounded in the $20^{\text {th }}$ Century. Also, it recognises that any other prohibition regime, either national or international, can be implemented by the military, causing a violent conflict beyond disorganised crime.

Before that, this research is obliged to revise essential questions regarding the building of criminal wars literature upon convergences. One of the most critical matters is defining the threshold behind how to define it as war. Some scholars studying violence in Latin America have avoided using the term war because of the political and legal implications that it could entail. However, other scholars use the term war on drugs freely. Understandably, it helps to differentiate that from other forms of violence in Latin America. For example, there are guerrillas, vigilantes, paramilitary groups, and gangs in the region. Fortunately, Lawrence Freedman has made critical remarks regarding this debate:

War has always been as likely to be intra-state as inter-state. Recalling Weber's definition of states as monopolising legitimate violence within their borders, then internally or externally generated challenges to this monopoly are two sides of the same coin (Weber, 2004). Even during inter-state wars at least one party, and possibly both, will seek to stir up discontent and rebellion inside the enemy's territory. Given the range and the types of violence that can take place within states, wars of this sort are even harder to define and describe. This has encouraged the spread of the term to cover any violent conflict, for example between warlords, drug cartels, and even rival urban gangs. ${ }^{37}$

\section{$(\ldots)$}

Though 'war' will often be adopted as a metaphor whenever a conflict becomes angry or intense, the core meaning depends on the association with purposive violence. Simply put there can be no war without acts of warfare. It is not enough to break diplomatic relations, exert economic pressure, or threaten force without actually doing so (as in a 'cold war'). It is, as Dinstein argued, indispensable that some armed force be employed (Dinstein, 2005: 9-10). War involves organised, purposive violence, undertaken by one wilful group against another. ${ }^{38}$

$$
(\ldots)
$$

37 Freedman, Lawrence. "Defining war." In The Oxford Handbook of War. Oxford University Press, 2012, p.20.

38 Ibid. 
Without the element of violence, the study of war loses all focus. It does not, however, need states. There is no reason why wars between gangs or other organised and semiorganised groups cannot be discussed in similar terms. After all, war pre-dates states and in its earlier forms probably took place as small communities competed over access to fertile land or proximity to water. For the violence to be purposive, it must be to a degree strategic. It must be geared to an end other than whatever satisfactions are derived directly from the experience of violence. Street fights, random displays of hostility, or 'letting off steam' do not count. ${ }^{39}$

In the historical sense that Freedman defends, war is ingrained in the political willingness of using violence against an opponent, in the tradition of Clausewitz study of conflict. ${ }^{40} \mathrm{~A}$ common misunderstanding of researchers on crime and violence in Latin America is that they believe that political objectives are ideological. That explains why they struggle with defining the violence in the region, either by avoiding using the word war or using it without conceptual care. Even military historians have been clear that ideology is not the only driver of war. ${ }^{41}$ Political goals are not the same as ideological purposes or change of the ruling class. Indeed, revolutions and civil war have ideological motivations, but the ideology rooted is in criminal insurgencies' organisational goals, not individual non-state combatants' motives. However, just by reading Freedman's argument, war comes from the challenger against the State and comes from the State itself.

Furthermore, militarised means the use of the armed forces and their warfare techniques. The diffusion of anti-terrorist, ${ }^{42}$ counterinsurgency, ${ }^{43}$ and kingpin strategies ${ }^{44}$ through the military or police forces in Latin America not only represents the use of the rule of law as the declaration of conflict against the criminal organisations. It is also the State's willingness to use militarised violence to control either gangs or drug cartels as the State's enemies.

Indeed, a plausible counterargument for using the concept of war is that there is a legal framework entwined with it. As Teiner points out, the hesitancy of using this concept comes from the fear that it could reinforce drug policy securitisation in the region ${ }^{45}$. However, as

39 Ibid.

40 Von Clausewitz, Carl. On war. Princeton University Press, 2008.

41 Soutou, Georges-Henri. "How History Shapes War." In The Oxford Handbook of War. 2014., p. 54. "The traditional, Clausewitzian, European type of war, with declaration of war, orderly surrender or armistice, and afterwards peace treaty, with its insistence on jus ad bellum and jus in bello, is no longer the rule, but rather the exception, if that. We have left an era of clear-cut difference between time of war and time of peace, and we have reached a state of continuous, diffuse violence. For the historian, this recalls prerevolutionary Europe. At the same time it would seem, from a steady evolution of international law and political thinking and public opinion since 1919 (if not earlier) that for Western-type societies the use of sustainable force cannot be contemplated without an accompanying political process aimed at war termination, without a major effort directed to the civilian population, and without an international mandate."

42 Felbab-Brown, Vanda. "The crime-terror Nexus and its fallacies." The Oxford Handbook of Terrorism (2019): 366-383.

43 Felbab-Brown, Vanda. Shooting up: Counterinsurgency and the war on drugs. Brookings Institution Press, 2009.

44 Pérez Ricart, Carlos A. "Taking the War on Drugs Down South: The Drug Enforcement Administration in Mexico (1973-1980)." The Social History of Alcohol and Drugs 34, no. 1 (2020): 82-113.

45 Teiner, David. "Cartel-Related Violence in Mexico as Narco-Terrorism or Criminal Insurgency." Perspectives on terrorism 14, no. 4 (2020): 83-98. Also revised earlier by Bullington, Bruce, 
Andreas and Price have registered for the United States, this was already undergoing. ${ }^{46}$ To be precise, the legal framework behind these conflicts is the international prohibition regime and the regime for transnational organised crime. ${ }^{47}$ There is no need for a formal declaration in countries' internal law or a United Nations Security Council's determination to determine violent internal conflict.

The debate of the legal status of conflict within a country depends on political determinations in legislative bodies. However, war can begin without any legal mechanism happening. The analytical facts that define social research are the ground's events, not legal or verbal declarations. Presidents and prime ministers in the region have proposed several names for their efforts: democratic security policy in the case of Uribe in Colombia, "mano dura" or "super mano dura" in the case of Presidents Francisco Flores and Antonio Saca in El Salvador, combat against organised crime for Felipe Calderón in Mexico, or declaring drugs as the number one enemy by Richard Nixon said in the U.S. However, the vital analysis that has to be conducted surrounds how the State, authorities and political elite behave, not their communicational or legal actions.

Another counterargument is that high homicide rates can not constitute by itself a marker of a war. On different sides, Reuter and Collins coincide that fights and retaliations driven by local conflict are more part of the realm of urban street violence. ${ }^{48}$ From a different perspective, Eisner, echoing Norbert Elias's work, argues that violence also comes from other types of expressions such as honour killings. ${ }^{49}$ Bergman, ${ }^{50}$ endorsing social disorganisation and opportunity theory in general, poses that economic growth and social process also have a role in local violent disputes. These authors do not deny violence's organisational dimension because only Bergman's work is about Latin America. Nevertheless, they are sceptic that only one main driver explains all homicides (very similar in civil wars debate).

and Alan A. Block. "A Trojan horse: Anti-communism and the war on drugs." Contemporary Crises 14, no. 1 (1990): 39-55. On securitization revise: Buzan, Security.

46 Andreas, Peter, and Richard Price. "From war fighting to crime fighting: transforming the American national security state." International Studies Review 3, no. 3 (2001): 31-52.

47 Berdal, Mats, and Mónica Serrano. "Transnational organized crime and international security: the new topography." Transnational Organized Crime and International Security: Business as Usual? (2002): 197207. Serrano, Mónica. "Business as Usual?." Transnational Organized Crime and International Security: Business as Usual? (2002): 13-36.

48 Collins, Randall. Violence: A micro-sociological theory. Princeton University Press, 2009, p. 1. "Young men, yes, are most likely to be perpetrators of many kinds of violence. But not all young men are violent. And middle-aged men, children, and women are violent too, in the appropriate situations. Similarly with background variables such as poverty, race, and origins in divorce or single parent families." Reuter, Peter. Disorganized crime: The economics of the visible hand. Cambridge, MA: MIT press, 1983.

49 Eisner, Manuel. "Modernization, self-control and lethal violence. The long-term dynamics of European homicide rates in theoretical perspective." British Journal of Criminology 41, no. 4 (2001): 618-638. Eisner, Manuel. "Long-term historical trends in violent crime." Crime and Justice 30 (2003): 83-142.

50 Bergman. More money, more crime, pp. 73-77. 


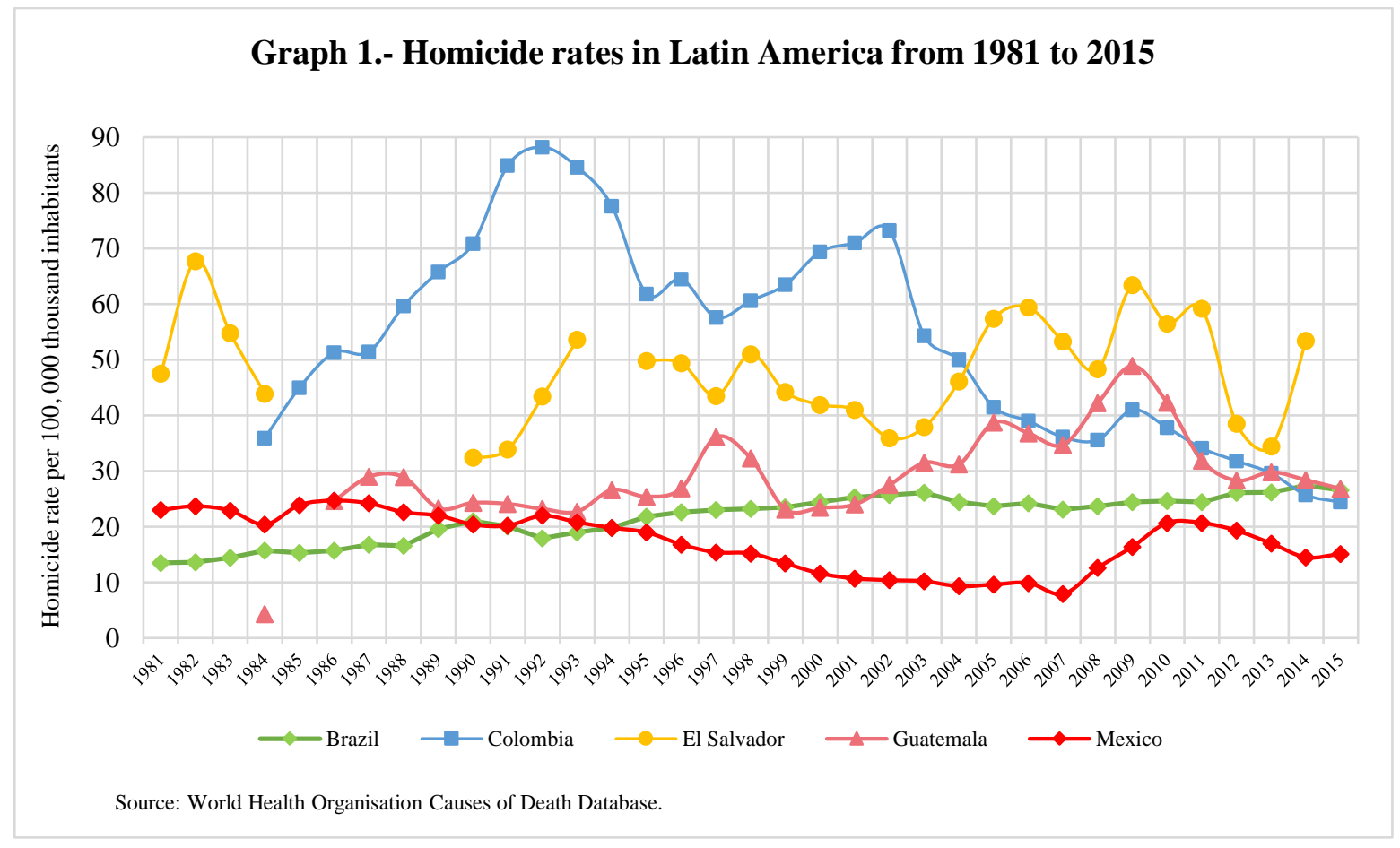

Graph 2.- Share of deaths from homicide by regions, 1990 to 2017

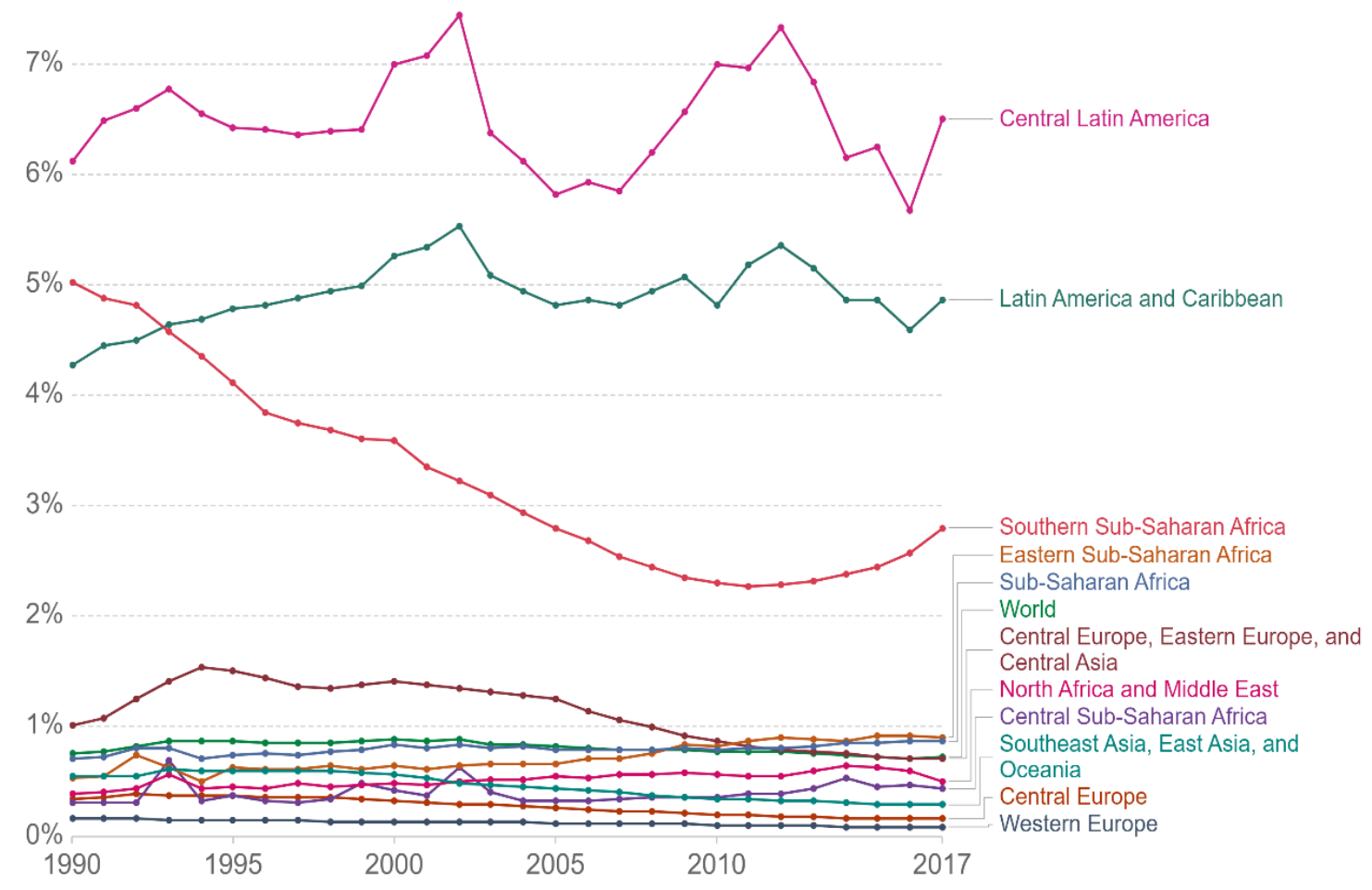

Source: Global Burden of Disease Collaborative Network. Global Burden of Disease Study 2017 (GBD 2017) Results. Seattle, United States: Institute for Health Metrics and Evaluation (IHME), 2018. Map: https://ourworldindata.org/homicides. 
Data trends in graph 1 show some fundamental changes in Latin America: the end of civil wars, the beginning of military-driven drug policies and gang suppression policies. Also, as shown in Graph 2, Latin America is the region with higher homicide rates. ${ }^{51}$ A case country that would seem an outlier could be Venezuela. However, recently Kronick has found that military drug operations in Colombia have transferred to the conflict Venezuela territory. These findings show how criminal wars have to be researched more from a regional scope. Criminal wars in some countries may affect others. ${ }^{52}$ On this debate, the Uppsala Conflict Data Program (UCDP) has defined non-state conflict as:

The UCDP defines non-state conflict as the use of armed force between two organised armed groups, neither of which is the government of a state, which results in at least 25 battle-related deaths in a year. In creating this definition, UCDP faced a number of challenges, the greatest of which was the question of whether a criterion of political motives should be required. In state-based conflicts, UCDP requires an incompatibility over government and/or territory. Following a long process which examined how 'incompatibilities' or 'political objectives' could be identified, UCDP found that any attempt to specify such a criterion in the context of non-state conflict would be unsystematic and subjective. ${ }^{53}$

Naturally, there is a coincidence of the UCDP non-state conflict concept with the interpretation of Freedman of Clausewitz conception of war in the realm of violent criminal activities. However, it is problematic because their classification is so broad that it includes non-state conflicts like Brazil, Colombia, Mexico, El Salvador, and Guatemala. And divergent cases such as Peru, Bolivia, Venezuela, and Ecuador. Again, as other scholars did, the UCDP examined non-state actors' motivations but disregarded governments' political willingness to use the military to implement the prohibition regime. That is why, by just counting and classifying without clear political distinctions, they merge ongoing criminal wars with cases with large-scale homicide rates. Some countries may be experiencing more street interpersonal violence rather than drug trafficking related. Adding up, just counting deaths as a probe of conflict is problematic for other reasons. Simultaneously, Bergman ${ }^{54}$ shows the low quality of homicide data in Latin America. Krause questions that researchers can immediately attribute those deaths to the conflict. ${ }^{55}$

Still, the historical coincidences between the international drug prohibition regime's policies and homicide trends have proven a more amicable explanation of increasing that any other variable. Nevertheless, to round up this argument: this research disbelieves the UCDP because they exclude the State's motivations (not the non-state actors). They commit the same misidentification that brings a country with high scale violence into the conflict realm without

51 Data also reported in Mandela, N.B, World report on violence and health, and United Nations Office on Drugs and Crime. Global Study on Homicide.

52 Kronick, Dorothy. "Profits and Violence in Illegal Markets: Evidence from Venezuela." Journal of Conflict Resolution 64, no. 7-8 (August 2020): 1499-1523.

53 Sundberg, Ralph, Kristine Eck, and Joakim Kreutz. "Introducing the UCDP Non-State Conflict Dataset." Journal of Peace Research 49, no. 2 (March 2012): 352-353.

54Bergman. More money, more crime, p. 315.

55 Krause, Keith. "Challenges to counting and classifying victims of violence in conflict, post-conflict, and non-conflict settings." Counting Civilian Casualties: An Introduction to Recording and Estimating Nonmilitary Deaths in Conflict (2013): pp. 265-284. 
considering the dimension of prohibition regimes. However, quantitative evidence is useful to understand the massive toll of deaths, and therefore, mobilisations. Moreover, massive violence must be understood with a theoretical framework regarding structural and mesoorganisational conflict processes that war studies bring.

Indeed, it seems paradoxical that weak states can wage war against seemingly powerful criminal organisations. Literature about mafias usually empathises that the State tolerates and negotiates with them, either by peaceful pacts or corruption. ${ }^{56}$ However, it is crucial to avoid the scholars and journalists who use failed State as a valid concept by misunderstanding the State of Weber's concept as an absolute rather than ideal type. ${ }^{57}$ It must understand the State not as a monolith because even Weber never understands it in that way. The State gathers bureaucracy and leadership in various organisations, so implementing the prohibition regime can stand. At the same time, there can be corruption within organisations and bureaucrats, including the military.

The presence of the State in Latin America has not been historically not uniformed in the territory. Moreover, government policy capacities are considerably underdeveloped. These structural conditions came from the urgent need to build professional armies for the wars waged in Latin America during the $19^{\text {th }}$ Century. Therefore, armies came first, civil bureaucracies later, and police enforcement agencies were the last until the current days. ${ }^{58}$ In this sense, the State's formation in Latin America diverges from the European states' statebuilding process. ${ }^{59}$

In Latin America, the State has developed in a more diachronic process: the elites in the region-built governments waging wars between political factions, but for territorial control, these states not necessarily established central control as the European States. For example, States and elites in the region recurred mediating figures and brokers as caciques and caudillos. ${ }^{60}$ Latin America states could reach some degree of control by several means. Some

56 Gambetta. The Sicilian Mafia, pp. 214-220.

57 Weber, Max. Weber's Rationalism and Modern Society. Translated and Edited by Tony Waters and Dagmar Waters (New York: Palgrave Macmillan), 1946, 2015 edition. Revise Politics as Vocation, p. 33 for the state concept. For the ideal type approximation Weber, Max, "Objectivity in Social Science and Social Policy" in The Methodology of the Social Sciences, E. A. Shils and H. A. Finch (ed. and trans.), New York: Free Press, 1904/1949, p.90.

58 O'Donnell, Guillermo. "On the state, democratization and some conceptual problems: A Latin American view with glances at some postcommunist countries." World Development 21, no. 8 (1993): 1355-1369. In terms of Mann, the Latin American State has increased its capacity to use violence, but it is not uniform in the territory. Furthermore, it is weak in policy capacities. Mann, Michael. "Infrastructural power revisited." Studies in Comparative International Development 43, no. 3-4 (2008): 355.

59 To understand the process of formation of European states and war-making against bandist, revise: Tilly, Charles. "War-Making and State-Making as Organized Crime, In Bringing the State Back In, (edited by Peter Evans, Dietrich Rueschemeyer, and Theda Skocpol)." (1985): 169-191. Olson, Mancur. "Dictatorship, democracy, and development." American Political Science Review (1993): 567-576. Hobsbawm, Eric, Bandits, Weidenfeld \& Nicolson, London, 2000.

60 Caciques are known as 'strong men' that had enough power through political recognition, charisma or military force to rule informally in a locality. Caudillos are known as popular military leaders that can rule without civilian control. These figures have been known as brokers in local politics in Latin America. For a wide discussion revise: Pansters, Wil G. "'Goodbye to the caciques? Definition, the state and the dynamics of caciquismo in twentieth-century Mexico'." Caciquismo in twentieth-century Mexico (2005): 349-376. Wolf, Eric R., and Edward C. Hansen. "Caudillo politics: A structural analysis." Comparative studies in society and history 9, no. 2 (1967): 168-179. 
of them via informal institutions because of the burden of debt imposed by European countries. After periods of civil wars, Latin America countries behaved as normal States by gathering formal armies. However, they never confronted similar challenges as the European States as waging wars, just brief conflicts with their neighbours. ${ }^{61}$ In this sense, since Latin America's independence, the prohibition regime's implementation has become the region first war-making as a state-building endeavour, with mixed results.

Bergman, Trejo and Ley, Koonings, Castillo and Kronick, Lessing, and Durán Martínez frame their research agenda on state capacity, with different tones of emphasis on factors behind the increase of violence in Latin America since the 1990s. ${ }^{62}$ As they recognise, criminal organisations are seeking to change governmental policies of enforcement. However, the difference between them comes when the State uses violence at higher levels, for example, by conducting military operations or beheading organisations.

Change into violent enforcement causes what Bergman calls a high violent equilibrium, Lessing as violent lobbying, Castillo and Kronick as interdiction. Against State military enforcement, criminal organisations have to dissuade using violence to stop the disruption of their traffic activities. ${ }^{63}$ Moreover, they use violence strategically to confuse authorities to confront their competitors. ${ }^{64}$ Even these organisations can employ violence on a large scale to provoke a de-escalation from the government. ${ }^{65}$ Also, these tactics can create an opportunity for monopolising trafficking routes. ${ }^{66}$

On the other hand, Trejo and Ley, Koonings, and Yashar point out that criminal organisations also look for monopolising regions. Some agents of the state grant protection by corrupt agreements, as the mafias literature usually poses. These findings converge with the civil war literature that Lessing has identified: criminal governance. Criminal organisations, as well as guerrillas, tend to govern spaces to advance their objectives. Indeed, objectives are not the same, but buying territorial management and corrupting authorities is

61 On this, revise Centeno, Miguel Angel. Blood and debt: War and the nation-state in Latin America. Penn State Press, 2002.

62 Bergman. More money, more crime. Chapter 6, Trejo and Ley, Votes, Drugs, and Violence, Chapter 1, Koonings, "New Violence, Insecurity, and the State", Lessing, Making Peace in Drug Wars, Chapter 3, Castillo and Dorothy Kronick. "The Logic of Violence in Drug War.", Durán Martínez, The Politics of Drug Violence, Chapter 2.

63 The literature on these dynamics is broad, but some examples are useful. Phillips has found how beheading criminal organisations causes long cycle of violence because it disrupts leadership within criminal organisations and creates power vacuums, also he found that criminal organisations uses terrorist tactics to signal competitors ("calentar la plaza" Duran argues) and dissuade the stat. Phillips, Brian J. "How does leadership decapitation affect violence? The case of drug trafficking organizations in Mexico." The Journal of Politics 77, no. 2 (2015): 324-336. Phillips, Brian J. "Terrorist tactics by criminal organizations: The mexican case in context." Perspectives on Terrorism 12, no. 1 (2018): 46-63. Durán-Martínez, Angélica. "To kill and tell? State power, criminal competition, and drug violence." Journal of Conflict Resolution 59, no. 8 (2015): 1377-1402.

64 Atuesta, Laura H. "Narcomessages as a way to analyse the evolution of organised crime in Mexico." Global Crime 18, no. 2 (2017): 100-121. Phillips, Brian J., and Viridiana Ríos. "Narco-messages: Competition and public communication by criminal groups." Latin American Politics and Society 62, no. 1 (2020): 1-24.

65 Atuesta, Laura H., and Aldo F. Ponce. "Meet the Narco: increased competition among criminal organisations and the explosion of violence in Mexico." Global Crime 18, no. 4 (2017): 375-402.

66 Ramírez-de-Garay, David. "Las barbas del vecino. Los patrones de difusión del crimen violento en México (1990-2010)." Foro internacional 56, no. 4 (2016): 977-1018. 
part of the repertoire of conflict and war. ${ }^{67}$ On this matter, rather than an apparent contradicting fact, war-making, state weakness, and criminal governance are deeply enmeshed parts of the complexity of criminal wars.

\section{Avoiding the greed and grievance framework}

By solving the criminal war query by the State's actions and not by criminal organisations' nature, this research avoids reproducing concept stretching done by the greed and new wars proponents. Neither the notion of "new wars" nor "economic civil war" addresses criminal wars' current dynamic. Even empirically, research on Latin America cases of civil wars could not fit into those categories. That shows their inner incapacity to describe trends of conflict. Francisco Gutiérrez Sanín makes the case of Colombia in which, indeed, some guerrillas used drug trafficking to fund their activities. However, it was not as rewarding as the conception of new wars portrayed ${ }^{68}$ Also, preliminary results from the recent demobilisation process of the FARC in Colombia show that most members of this organisation effectively demobilised after the peace agreement instead of converging into drug trafficking. This finding challenges the idea that economic motivation was enough to participate in a civil war. $^{69}$

There is no denying of the conflict's economic dimension, but rather challenge a pure economic vision that does not consider politics, history, or other cultural dimensions. The political economy perspective proposed by Keen and Berdal on the matter sheds light on the question: war can change economic trends, and economic trends feed conflict dynamics. ${ }^{70}$ This research concurs and recuperates the scope of Polanyi: economic phenomena depend on

67 Lessing, Benjamin. "Conceptualizing Criminal Governance." Perspectives on Politics (2018): 1-20. Rich literature has come in this matter: Arias, Enrique Desmond. "The dynamics of criminal governance: networks and social order in Rio de Janeiro." Journal of Latin American Studies (2006): 293-325. Mattiace, Shannan, Sandra Ley, and Guillermo Trejo. "Indigenous resistance to criminal governance: why regional ethnic autonomy institutions protect communities from Narco rule in Mexico." Latin American Research Review 54, no. 1 (2019): 181. And Magaloni, Beatriz, Edgar Franco-Vivanco, and Vanessa Melo. "Killing in the Slums: Social Order, Criminal Governance, and Police Violence in Rio de Janeiro." American Political Science Review 114, no. 2 (2020): 552-572. Pansters, W.G. Drug trafficking, the informal order, and caciques. Reflections on the crime-governance nexus in Mexico. Global Crime, 19, 2020, (pp. 315$338)$.

68 Gutiérrez Sanín, Francisco. "Clausewitz Vindicated. Economics and Politics in the Colombian War." Order, Conflict, and Violence (2008): 219-241. Sanín, Francisco Gutiérrez. "Criminal rebels? A discussion of civil war and criminality from the Colombian experience." Politics \& Society 32, no. 2 (2004): 257-285.

69 The last report of the United Nations Verification Mission in Colombia reports that more than 10 thousand members of the FARC demobilised, and most of them live in the regions where FARC used to operate (S/2020/943, link: https://www.securitycouncilreport.org/atf/cf/\%7B65BFCF9B-6D27-4E9C-8CD3CF6E4FF96FF9\%7D/S 2020 943_E.pdf). Even, the reintegration of Iván Márquez to guerrilla activities, there has not been registered a massive defection to the demobilisation process. Yet, the president Iván Duque has made efforts to undermine the peace process, but that proves again that politics is part of the dynamics of conflict beyond economics.

70 Berdal, Mats, and David Keen. "Violence and economic agendas in civil wars: some policy implications." Millennium 26, no. 3 (1997): 795-818. Berdal, Mats. "Beyond Greed and Grievance: And Not Too Soon... A Review Essay." Review of International Studies 31, no. 4 (2005): 687-698. Keen, David. "Greed and grievance in civil war." International Affairs 88, no. 4 (2012): 757-777. Berdal, Mats. "How "new" are "new wars"? Global economic change and the study of civil war." Global Governance: A Review of Multilateralism and International Organizations 9, no. 4 (2003): 477-502. Keen, David. "The economic functions of violence in civil wars." The Adelphi Papers (2005). 
political decisions. ${ }^{71}$ Even if the dynamics and rationale of criminal wars depend on economic rent-seeking choices, the State regulating those by force and not by marketoriented policies is political.

The greed and grievances debate has resonated in the criminal war literature because it is grounded in the microeconomic rational choice proposals that have also influenced organised crime, mafia, and criminology literature. Moreover, this research does not deny the rentseeking rational behaviour of criminal organisations. However, as Elster reviews in Marxist thinking, material needs are based on human nature and not the only driver. Material rationality is part of the cogs and wheels of studying human behaviour, but not the only one. ${ }^{72}$ Therefore, convergences regarding economic rationality are common. However, the study's demarcation was needed to not fall into invalid comparisons: guerrillas and criminal organisations, of all different types and styles, are indeed very different.

Also, part of the main problem that has led to these debates comes from the excessive use of one methodology and level of analysis for building theory. In the case of the debate of greed and grievances, there are two primary considerations to caveat: first, the overemphasis with causes of the onset of conflict. By discussing the work of Collier and Hoeffler, ${ }^{73}$ researchers were either eager to disprove or support their thesis (the central core of their theory) than actually understanding onset. Dixon noted that more than 200 independent variables arise while testing this theory, and the results were somewhat mixed and contradictory. ${ }^{74}$ This finding has a reason behind it: the large $\mathrm{N}$ studies have several limitations regarding measuring problems, data scarcity, too many different proxies of the dependant variable, and many omissions. Unfortunately, scholars tried to understand criminal wars using the premises of this debate. Moreover, they replicated the same contradictory assumptions in a field that was not theoretically as developed as the literature of civil wars and revolutions. Nowadays, researchers of civil wars have shifted towards micro-dynamics and case studies rather than large $\mathrm{N}$ comparisons. ${ }^{75}$

Furthermore, in the continuing effort to support or discard the Collier and Hoeffler thesis' central core, by only doing large $\mathrm{N}$ studies to create supposedly universal results, researchers forgot different analysis levels: survey data, spatial local data, interviews, historical accounts, and perception studies. Cederman, Gleditsch and Buhaug noted that they could find a strong

71 Polany, Karl, The Great Transformation. The Political and Economic Origins of Our Time, Beacon Press, New York, 1944.

72 This is discussed by Elster, Jon. Making sense of Marx. Cambridge University Press, 1985, pp. 53-92, and Elster, Jon. Nuts and Bolts for the Social Sciences. Cambridge: Cambridge University Press, 1989, pp. 1188.

73 The debate surged from the seminal paper Collier, Paul, and Anke Hoeffler. "Greed and grievance in civil war." Oxford Economic Papers 56, no. 4 (2004): 563-595. Although this research recognises the importance of this debate to promote a wider understanding of conflict beyond the stalemate of ideology and ethnicity, this also obscured complexities of conflict and war that were obscured in mainstream debates. Indeed, Collier and Hoeffler, in response to the debate surged by their initial paper, have replaced their view from pure onset to feasibility, but their main core of the theory in terms of Lakatos was the same: greed as driver. Collier, Paul, Anke Hoeffler, and Dominic Rohner. "Beyond greed and grievance: feasibility and civil war." Oxford Economic Papers 61, no. 1 (2009): 1-27.

74 Dixon, Jeffrey. "What causes civil wars? Integrating quantitative research findings." International Studies Review 11, no. 4 (2009): 707-735.

75 Kalyvas, Stathis N. "Micro-level studies of violence in civil war: Refining and extending the controlcollaboration model." Terrorism and Political Violence 24, no. 4 (2012): 658-668. 
relationship between horizontal inequalities and violence. Their finding concurs with criminology literature on homicides. They studied the same variables used in large $\mathrm{N}$ studies. However, instead, they used spatial data modelling in more disaggregated geographical analysis units. ${ }^{76}$

Strikingly, many studies also quoted Ted Gurr work with the research of Collier and Hoeffler as the founding strain of the study of greed in the discussion. This framing happened because of Gurr's focus on relative deprivation theories and alleviation of deprivation as the source of greed. Nevertheless, Gurr's concept and methods in his seminal book, Why Men Rebel, are far apart from Collier and Hoefller approach. For example, Gurr uses the definition of relative deprivation as perceived discrepancies on values, expectations, and capabilities due to inequality. This angle was more in concurrence with Durkheimian sociological theories of anomie. Nonetheless, research derived from the Collier and Hoeffler focuses wrongly assumed that those could be measured only using income inequality and the Gini Index. ${ }^{77}$

Gurr proposes a careful case of mechanisms between material deprivation, psychological drivers of aggression, and political motivations. Moreover, that is why he proposes values surveys and not large N comparisons of income inequality. Gurr was thinking in individual and behavioural attitudes, not aggregated indexes of income surveys on households. ${ }^{78}$ Also, he recognises in the 2016 edition of his book that his research did not consider rent-seeking rationality or collective action literature. ${ }^{79}$

Nonetheless, the lessons of these debates give us pathways for research: the economic dimension is relevant, the political motivation of the criminal wars are relevant, and this subject of knowledge, the motivations, emotions, and rational behaviour of those mobilised matter. Rather than large $\mathrm{N}$ studies, the current literature on Latin America has tried to engage in case studies. In the building of criminal war theory, a lesson to emphasise is not confusing individual motivations, organisational behaviours, and macrostructural and political trends of the conflict. This view was the main criticism from Tilly to Gurr. ${ }^{80}$ Tilly argues that changing levels of analysis, and stating that one level explains the other automatically, without considering their causal mechanisms, falls into an ecological fallacy. A fallacy that also Collier and Hoeffler committed. Moreover, scholarly fields as sociology and organised crime literature have advanced not only methods but also understanding of human behaviour.

76 Cederman, Lars-Erik, Kristian Skrede Gleditsch, and Halvard Buhaug. Inequality, grievances, and civil war. Cambridge University Press, 2013. On criminology literature, may of the studies are done in neighbour levels. For this revise the work of Sampson, Robert J., Stephen W. Raudenbush, and Felton Earls. "Neighborhoods and violent crime: A multilevel study of collective efficacy." Science 277, no. 5328 (1997): 918-924.

77 Gurr, Ted Robert. Why men rebel. Routledge, 2016. p. 13

78 Ibid, pp. 369-379. This section is the bibliography separated by fields, this section is called "Behavioral and attitudinal studies".

79 Ibid. pp. ix-xix. In this section, the two main authors that Gurr quotes as fundamental criticisms to his work are Tilly, Charles. The politics of collective violence. Cambridge University Press, 2003. and Lichbach, Mark Irving. The rebel's dilemma. University of Michigan Press, 1998.

80 Tilly, Charles. "Why Men Rebel. By Ted Robert Gurr. (Princeton: Princeton University Press, 1970. Pp. xi+ 421. \$12.50)." Journal of Social History, (1971): 416-420. 
From these fields, rationality, culture, and emotions are complementary rather than opposed. $^{81}$

As said before, by only revising some variables or using large $\mathrm{N}$ studies, one aspect is relevant: motivations, structural factors, or opportunities. ${ }^{82}$ On this matter, this research concurs with Boix. It is essential to understand opportunities and motivations congruently from a more historical process perspective. Rather than opposed, opportunities lead to mobilisation. Simultaneously, motivations are present, but structural conditions also affect changing life pathways of eventually mobilised individuals into conflict. ${ }^{83}$

On this, Angélica Durán-Martínez opened the door smoothly: as she notices, the challenge of the State by using military interventions made that drug-trafficking organisations and mafias had to make alliances between organisations with more firebrand capacity, sign up individuals into their criminal racketeering branches, or even subsume gangs into their control. That is what she calls insourcing and outsourcing violence. ${ }^{84}$ Concurring and even reinforcing this concept: human resources in capitalism are part of industrial transformations.

Durán-Martínez argues that criminal organisations used outsourcing as a labour recruitment technique. In outsourcing, recruiters sell their enrolled labour force to the temporary contactor. ${ }^{85}$ The more classical historical term for this activity is a mercenary. ${ }^{86}$ This process's exemplary case was the creation of 'Los Zetas', a former military organisation, as a Mafiosi labour force once contracted by the 'Golfo' Cartel. ${ }^{87}$ This recruitment process also happened with the 'Sinaloa' Cartel. They recruited local gangs into their national organisation under the command of the 'Beltrán Leyva' brothers. ${ }^{88}$ Both 'Los Zetas' and

81 It is interesting to find how in computing science, while trying to understand behaviour as rational, they have found that emotions play a major role in decision making because it integrates information and shapes reaction, not only as a kind of irrational response of the human, rather an integral part of it. This ca be read in Picard, Rosalind W. Affective computing. MIT press, 2000. On cultural and societal behaviour, Bowles and Gintis propose that cooperation and reciprocation, rather than individual rent seeking behaviour, is the main foundation of human society: Bowles, Samuel, and Herbert Gintis. A cooperative species: Human reciprocity and its evolution. Princeton University Press, 2013. On a neurobiology perspective, several authors have recognised the variety of emotional developments linked to violence. This will be addressed them in the next chapter, but a first approximation can be read in Loeber, Rolf, and Dustin Pardini. "Neurobiology and the development of violence: common assumptions and controversies." Philosophical Transactions of the Royal Society B: Biological Sciences 363, no. 1503 (2008): 2491-2503.

82 Also, while demographic change is important, a new branch of researchers have propose "cliodynamics" or the mathematical prediction of violent conflicts though the study of economic and demographic indicators. This research is sceptic of the forecasting approach, but will address the relevancy of demographic change in this thesis. To revise: Turchin, P. 2008. "Arise 'cliodynamics'." Nature, 2008, pp. 454: 34-35. Turchin, Peter and Andrey Korotayev. "The 2010 Structural-Demographic Forecast for the 2010-2020 Decade: A Retrospective Assessment.” PLOS ONE, 2020.

83 Boix, Carles. "Civil wars and guerrilla warfare in the contemporary world: toward a joint theory of motivations and opportunities." In Order, conflict, and violence (2008): 197-218.

84 Durán Martínez, The Politics of Drug Violence, pp. 14-18.

85 Ibid.

86 Avant, Deborah. "From mercenary to citizen armies: Explaining change in the practice of war." International Organization (2000): 41-72.

87 Aguayo, Sergio, and Jacobo Dayán. El yugo Zeta: norte de Coahuila, 2010-2011. El Colegio de Mexico AC, 2018.

88 De Mauleón, Héctor, "La ruta de sangre de Beltrán Leyva”, Nexos, February, 2010. https://www.nexos.com.mx/?p=13503 
'Beltrán Leyva' gained independence afterwards. As it will be argued, concurring with DuránMartínez, this process of creating human armies needed to be fast to confront the State. Outsourcing was a method widely used in Mexico.

Moreover, while revolutions are different, Theda Skocpol, in her seminal book, States and Social Revolutions, describes one of the most critical political violence opportunities: stateweakness. Suppose non-state actors, revolutionaries in Skocpol, calculate that they have enough force to contest the State again. In that case, they will engage in political violence. ${ }^{89}$ Tarrow and Tilly's theory of resource mobilisation for collective action relies upon the same premise. Collective action against the State needs resource mobilisation to pose a credible challenge to the State. ${ }^{90}$ The differences between criminal organisations and guerrillas relay that both can collect weapons and gain profits from illicit activities to amass enough resources to confront the State. However, criminal organisations can evade the State and transform themselves because their organisational goals are different.

\section{Conclusions}

Since the 1990s in Latin America, criminal organisations benefited from a growing drug illicit market like the United States. ${ }^{91}$ Also, the deregulation of guns in that country lead to massive traffic of guns. ${ }^{92}$ Rapidly there were fewer barriers to international trade due to the expansion of free trade agreements. ${ }^{93}$ The liberalisation process leads to more opportunities for illicit trade through borders and cargo ships. These economic changes happened in highly unequal but growing economies with a large youth bulge. Combining these factors created the ideal preconditions for criminal wars: a perfect storm of state-weakness and resource possibilities to create armies. Soon after, States created the opportunity for violent conflict by prosecuting criminal organisation through military techniques. Paradoxically, although the outcomes have been disastrous, governments in Latin America continue to respond to international prohibition demands. Mainly, these demands come from the U.S. Government.

89 Skocpol, Theda. States and social revolutions: A comparative analysis of France, Russia and China. Cambridge University Press, 1979.

90 Tarrow, Sidney G. Power in movement: Social movements and contentious politics. Cambridge University Press, 2011. Tarrow, Sidney, and Charles Tilly. "Contentious politics and social movements." In The Oxford Handbook of Comparative Politics. 2007. Tilly, Charles. The politics of collective violence. Cambridge University Press, 2003.

91 Bergman. More money, more crime. Chapter 3.

92 Dube, Arindrajit, Oeindrila Dube, and Omar García-Ponce. "Cross-border spillover: US gun laws and violence in Mexico." American Political Science Review (2013): 397-417. Esparza, David Pérez, and Eugenio Weigend. "The illegal flow of firearms from the United States into Mexico: A state-level trafficking propensity analysis." Journal of Trafficking, Organized Crime and Security 1, no. 2 (2015): pp-115.

93 Duffield, Mark. "Globalization and war economies: Promoting order or the return of history." Fletcher F. World Aff. 23 (1999): 21. 